DOI https://doi.org/10.30525/978-9934-26-073-5-1-43

\title{
ЧАСО-ПРОСТОРОВІ ОСОБЛИВОСТІ РОМАНІСТИКИ ПАНАСА МИРНОГО
}

\author{
Хачатурян К. Р. \\ старший викладач кафедри мовної підготовки 1 \\ Навчально-наукового інституту міжнародної освіти \\ Харківського національного університету імені В. Н. Каразіна \\ м. Харків, Україна
}

Кінець XIX - початок XX століття приніс до української літературознавчої критики багато нового, пов'язаного з природою мистецтва слова, з полемікою про сутність національного та загальнолюдського, 3 уявленнями про свободу творчості і шляхи розвитку літератури, про структурні особливості художніх творів. Як наслідок, з'явилася можливість досліджувати і оцінювати окремі літературні явища по-новому, в широкому історичному та теоретичному контекстах. У зв'язку з цим вельми значущим для подальшого осмислення української літератури здається, на наш погляд, розгляд художніх творів Панаса Мирного 3 точки зору просторово-часових характеристик.

По-перше, виявлення типологічної своєрідності героя прози Панаса Мирного: його психологічного портрета, душевно-естетичних якостей, моральності, ідеалів - дадуть нам можливість зрозуміти важливі художні особливості творчості письменника, а також більш глибоко розкрити особистісні аспекти самого автора. Важливо, що цей герой реалізується в долях реальних людей, зі своїми життєвими проблемами, в конкретних суспільно-історичних соціальних умовах.

По-друге, комплексне вивчення творчості Панаса Мирного, особливостей його романістики, єдності художнього простору і часу допоможуть визначити, яку роль і місце посідають особистість та творчість письменника в українській літературі і в загальноукраїнському літературному русі.

По-трете, вивчення романістики письменника в аспекті поетики художнього простору і художнього часу, а також пов'язаних 3 ними ідей та проблематики будуть істотно сприяти сприйняттю людини як головного предмета мистецтва, у зв'язку з суспільством, дозволить прослідкувати еволюцію героя та трансформацію стильових тенденцій в українській літературі кінця XIX - початку XX століття. 
Поняття часу i простору в їх філософсько-естетичній постановці несуть універсальний характер, а за широтою використання в різних галузях наукового знають мають глобальне значення. На думку А. Абасова в даному випадку мова йде про те, що у «порівнянні 3 іншими поняттєвими категоріями, що входять сучасної наукової та філософської думки, поняття художнього просторо-часу своєю тотальною участю вражає усі галузі людський знань» [1, с. 48].

Художня література специфічна в освоєнні простору i часу. Ф. Федоров висловлює думку про те, що уявлення про людину i суспільство, просторова структура художніх творів авторів сходиться в залежності від просторово-часової структури, від історико-культурної свідомості [2, с. 94].

У зв'язку з цим, літературознавець В. Гак справедливо стверджує, що нероздільною частиною матерії $\epsilon$ і простір, і час. Вчений зауважує, що «така форма буття організовується навколо людини, будучи засобом пізнання навколишнього світу. У таких випадках простір і час легше сприймаються» [3, с. 127], тому час і простір взаємопов'язані.

Дослідження з типології художнього простору і часу представляють особливий інтерес. Роботи А. Єсіна, А. Гуревича, Б. Успенського, Б. Кормана, В. Щукіна, В. Топорова, Д. Лихачова, Ю. Лотмана мають особливе значення при вивченні художнього часу і простору в літературознавстві.

В романістиці Панаса Мирного ми виділяємо наступні види художнього простору: соціально-побутовий, психологічний, міфологічний, географічний та простір природи. Ми розглянемо деякі з них.

Соціально-побутовий простір $\epsilon$ характерним типом художнього простору Панаса Мирного. В його творах яскраво відображені основні соціальні прошарки суспільство кінця XIX - початку XX століття. За словами М. Бахтіна «людина, що висловлюється в романі - це істотно соціальна людина і вона історично абстрактна. Слово людини в творах це суспільна мова, а не особистий діалект» [4, с. 146].

Психологічний простір відрізняється замкнутістю, зануреністю суб'єкта у внутрішній світ. Панас Мирний виділяє особисте духовне життя людини. Автор ставиться до своїх героїв дуже дбайливо: розкриває їх душу, переживання, думки, специфічні риси їх характеру. В центрі уваги письменника світ почуттів, емоцій, відчуттів та переживань, в якому організовуються всі основні явища суспільного існування. Психологізм творчості Панаса Мирного виражається через розкриття внутрішнього духовного життя героїв. Наприклад, у романі «Хіба ревуть воли, як ясла повні?» $€$ епізод другої зустрічі Чіпки з Галею, 
коли він, підкравшись, злякав дівчину: «Дівчина кинулась, злякалася; схопилась, щоб утікати, та, висипавши на землю квітку з фартушини, похопилася; знову опустилась на траву і стала обома руками гарбати й кидати назад у фартушину польове добро.

- А куди ти тепереньки втечеш від мене? - пита ії Чіпка.

- Я й тікати не буду... - перевівши дух, одмовила вона та й підвела на

його свої оксамитні очі. - О-ох... та й злякав же ти мене... хай тобі!

- Од іскристого погляду, од ії голосу, свіжого, дзвінкого, - так і

звився Чіпка. А хороша ж яка!.. а люба та мила!.. - промелькнуло у його думці. Він стояв перед нею мовчки та милувався такою вродливою красою. Мовчала й вона, підбирала квітки. Він осмілився - сів поруч 3 нею.

- Що це буде? - обізвався перший, показуючи на недопалений вінок.

- Хіба не бачиш? - вінок! - аж скрикнула.

Знову замовкли обоє. Він схилився біля неї трохи на лікоть та скоса поглядав на iї личко, що від такої несподіваної тривоги зашарілось, здається - пашіло полум'ям. Вона підбирала квітки та зав'язувала у невеличкі пучечки одномасних кольорів. Навкруги тихо, гарно, зелено; тільки буйні жита стиха шурчали довгими колосками, мов розмовляли 3 собою; од квіток пахощі разом з повітрям втяглись грудьми - i легко й мило було дихати...» [5, с. 48].

Міфологічний простір - загальнонародні перекази, оповіді, легенди, міфі та казки донесли до наших днів концептуальну єдність буття. Саме через ці народні легенди пізнаємо життя людей, які жили до наших днів. I сміливо можна сказати, що сьогоднішній побут має частинку минулого способу життя. I в теперішньому часу теж буде відображатися такий спосіб життя. Сдність героїв Панаса Мирного з простором природи, представлення різних людиноподібних образів природи говорять про міфологізм мислення автора. Прикладом може бути епізод з роману «Повія» «А небо - глухе, як пустиня, німе та холодне, як камінь, шатром розіслалося понад землею, морозом окувало іiі, давить, наче хоче задавити... Хто ж ії там почує?.. Хіба люди у селі? Та й село упокоїлось: не світиться ніде, собака гавкне - все заснуло мертвим сном. Людські оселі, наче могили, чорніють серед снігу... Німі та мовчазні, вони не кажуть, що у їх заводиться. Чи щасна доля доглядає сон їх житців, чи гірке лихо перевертає їх з місця на місце... Вони припали до землі від страшного холоду - i тільки з димарів виходе пара, даючи ознаку, що 
там, усередині їх, ще не прочахло тепло, ще тліє людське життя» [6, с. 156].

Міфологічний просторовий образ у романістиці Панаса Мирного являє собою особливий тип ментального простору і здійснюється крізь призми світовідчуття героїв. Такий вид простору вплітається в соціально-побутову сферу.

Художній світ романістики Панаса Мирного $є$ складною концептуально обгрунтованою структурою, де одна 3 детермінуючих ролей належить простору і часу.

\title{
Література:
}

1. Абасов. А. Пространство и время, пространственно-временная организация. Вопросы философии. 1985. № 11. С. 71-81.

2. Федоров, Ф. Романтический художественный мир: пространство и время. Рига: Зинатне. 1988. 567 с.

3. Гак В. Пространство вне пространства. Логический анализ языка. Языки пространств. Москва: Языки русской культуры, 2000. С. 127-134.

4. Бахтин, М.М. Эпос и роман (о методологии исследования романа). Вопросы литературы. 1970. № 1. С. 104.

5. Панас Мирний та Іван Білик. Хіба ревуть воли, як ясла повні? Київ : Радянський письменник, 1967. 333 с.

6. Мирний Панас. Твори в двох томах. Т. 2. Київ : Наук. думка, 1989. $634 \mathrm{c}$

DOI https://doi.org/10.30525/978-9934-26-073-5-1-44

\section{КОЛОРИСТИКА У БОРИСЛАВСЬКИХ ТВОРАХ ІВАНА ФРАНКА I СТЕФАНА КОВАЛІВА}

\author{
Шостак О. О. \\ кандидат філологічних наук, \\ методист навчально-методичного відділу \\ Рівненського державного гуманітарного університету \\ м. Рівне, Україна
}

У 1850-х рр. розпочалась індустріалізація Східної Галичини, пов'язана з видобуванням нафти. Основним промисловим центром став Борислав із сусідніми селами (Мразниця, Тустановичі, Східниця, Волянка). Травматичний процес руїни традиційного селянського побуту 